\title{
Efektifitas Terapi Kelompok Supportif Terhadap Kualitas Hidup Lansia Dengan Hipertensi
}

\author{
Duma L.Tobing1, Evin Novianti2 \\ 1,2Program Studi S1 Keperawatan UPN Veteran Jakarta \\ Jln.Limo Raya Keluarahan Limo,Cinere Depok \\ Email :duma@upnvj.ac.id, ${ }^{1}$ evinnovianti@upnvj.ac.id²
}

\begin{abstract}
Abstrak
Pendahuluan: Lansia dengan hipertensi tidak terlepas dari minum obat setiap hari, kontrol makanan, gaya hidup dan emosi yang setiap menitnya dapat mempengaruhi kualitas hidup lansia

Tujuan: Penelitian ini bertujuan untuk membuktikan efektivitas terapi kelompok suportif terhadap kualitas hidup lansia dengan hipertensi

Metode: Desain penelitian yang digunakan adalah Quasi experimental pre and post test with control group". Sampel penelitian berjumlah 44 orang yang dibagi dalam 2 kelompok yaitu kelompok intervensi dan kelompok kontrol

Hasil: Hasil penelitian menunjukkan nilai sig (2tailed) pre test dan post test dengan taraf signifikansi $0,0001(\mathrm{p}<0,05)$.

Kesimpulan : Hal ini menunjukkan bahwa ada pengaruh yang signifikan dalam pembentukan kelompok supportif terhadap kualitas hidup lansia dilihat dari empat domain yaitu fisik, psikologis, lingkungan dan sosial pada kelompok intervensi dibandingkan kelompok kontrol
\end{abstract}

Kata Kunci: hipertensi, lansia, kualitas hidup, terapi kelompok suportif,

\section{Pendahuluan}

Kemajuan ilmu pengetahuan dan teknologi di bidang ilmu kesehatan memberikan dampak positif dalam meningkatkan kualitas hidup dan peningkatan rata-rata usia harapan hidup. Keadaan ini menyebabkan jumlah populasi lanjut usia semakin besar bahkan cenderung lebih cepat dan pesat. ${ }^{1}$ Meningkatnya usia harapan hidup di Indonesia membuat jumlah orang lanjut usia (lansia) semakin banyak. Usia harapan hidup di Indonesia

\begin{abstract}
Introduction: Elderly with hypertension can not be separated from taking medication every day, food control, lifestyle and emotions that every minute can affect the quality of life of the elderly.

Objective: This study aims to prove the effectiveness of supportive group therapy on the quality of life of the elderly with hypertension

Method: The research design used was a quasi experimental pre and post test with control group ". The research sample consisted of 44 people who were divided into 2 groups: the intervention group and the control group

Results: The results showed the sig (2-tailed) value of pre-test and post-test with a significance level of $0.0001(p<0.05)$.

Conclusion: This shows that there is a significant influence in the formation of supportive groups on the quality of life of the elderly viewed from four domains namely physical, psychological, environmental and social in the intervention group compared to the control group
\end{abstract}

Keywords: hypertension, elderly, quality of life, group therapy supportive

meningkat dari 68,6 tahun di 2004 menjadi 70,8 tahun di 2015. Pada tahun 2035 diperkirakan meningkat lagi menjadi 72,22.

Seiring dengan meningkatnya prevalensi lansia, meningkat pula penderita hipertensi di indonesia mencapai $21 \%$ selanjutnya diestimasi akan meningkat menjadi 37 $\%$ pada tahun 2015 dan menjadi $42 \%$ pada tahun 2025. ${ }^{2}$ Hipertensi termasuk dalam kelompok penyakit tidak menular dan pada tahun 2020, diperkirakan kematian akibat 
penyakit tidak menular sebesar $73 \%$ dari seluruh kematian di dunia dan sebanyak $66 \%$ diakibatkan penyakit jantung dan pembuluh darah, gagal ginjal dan stroke, dimana faktor resiko utama penyakit tersebut adalah hipertensi. ${ }^{3}$ Hipertensi dapat meningkatkan lima kali resiko terkena penyakit jantung koroner. Perlunya pengobatan dan penanganan yang intensif untuk memperkecil komplikasi yang ditimbulkan dari hipertensi.

Pengobatan hipertensi membutuhkan waktu yang panjang bahkan seumur hidup lansia. Kondisi ini tidak hanya membebani perekonomian keluarga tapi juga kemampuan lansia melakukan aktififitas sehari hari. ${ }^{4} \mathrm{Ke}$ munduran kondisi fisik akibat hipertensi, mempengaruhi ketahanan tubuh lansia terhadap gangguan atau serangan infeksi dari luar. Hal inilah yang dapat memperberat kualitas hidup lansia. ${ }^{5}$

Lansia yang mengalami hipertensi yang terus menerus dan tidak mendapatkan pengobatan serta pengontrolan secara cepat akan berdampak pada kerusakan pembuluh darah jantung, ginjal, otak dan mata. Kerusakan jantung ini menimbulkan gejala seperti sakit kepala, kelelahan, nyeri dada, serta kesemutan pada kaki dan tangan sehingga dapat menyebabkan kualitas hidup lansia menurun6. Fungsi sistem tubuh lansia yang mengalami hipertensi dapat berdampak terhadap kualitas hidup baik dalam skala ringan, sedang maupun berat.

Hal tersebut didukung oleh hasil penelitian bahwa status kesehatan seperti hipertensi dapat mempengaruhi kualitas hidup. ${ }^{7}$ Hasil penelitian yang lain menunjukkan bahwa 51 lansia yang mengalami hipertensi, 40 orang $(78,4 \%)$ lansia mempersepsikan kualitas hidupnya rendah dan 11 orang $(21,6 \%)$ pada tingkat tinggi. ${ }^{6}$

Kualitas hidup yang rendah dihubungkan dengan kesehatan fisik, kondisi psikologis, hubungan sosial dan hubungan lansia dengan lingkungan. Kualitas hidup lansia dapat ditingkatkan melalui sistem pendukung dari keluarga dan di luar keluarga seperti adanya kelompok yang juga memiliki masalah yang sama dengan lansia. Dengan demikian, lansia dapat mengatasi masalahnya di dalam kelompok, dapat merasakan kesulitan-kesulitannya di dalam kelompok dan mencari jalan keluarnya. ${ }^{8}$ Masing-masing anggota kelompok akan memberikan support kepada anggota kelompok yang mengalami penurunan kualitas hidup akibat hipertensi yang dialami dengan cara mengklarifikasi permasalahan yang dihadapi lansia sehingga mampu memanfaatkan support system yang dimilikinya baik dari anggota kelompok yang lain maupun sistem dukungan. ${ }^{9}$ Dengan demikian, terapi supportif pada kelompok lansia dengan hipertensi ini dapat meningkatkan kualitas hidup lansia baik fisik, psikologis, sosial dan lingkungannya10.

\section{Metode}

Penelitian ini menggunakan desain penelitian "Quasi Experimental Pre-Post Test With Control Group" dengan intervensi Terapi Kelompok Suportif. Tehnik pengambilan sampel penelitian menggunakan purposive sampling dengan jumlah total sampel sebanyak 44 orang yang dibagi dalam kelompok intervensi dan kelompok kontrol.

Masing-masing kelompok berjumlah 22 orang. Sampel dipilih berdasarkan kriteria inklusi, yaitu berusia $\geq 45$ tahun, menderita hipertensi $\geq 6$ bulan, tidak mengalami dimensia, kesadaran kompos mentis dan bersedia sebagai responden

Instrumen penelitian menggunakan kuesioner yang terdiri dari data karakteristik responden yang meliputi usia, jenis kelamin, tingkat pendidikan, lama menderita diabetes mellitus dan keteraturan minum obat hipertensi. Data kualitas hidup didapatkan dengan menggunakan World Health Organization Quality Of Life (WHO-QOL). ${ }^{11,15}$ Analisis statistik yang dipergunakan yaitu univariat dan bivariat dengan analisis paired-t test

\section{Hasil}

Penelitian ini telah dilakukan pada 44 orang lansia yang menderita hipertensi yang terbagi menjadi kelompok intervensi sebanyak 22 orang dan kelompok kontrol sebanyak 22 orang. Karakteristik lansia dengan hipertensi dilihat berdasarkan usia, jenis kelamin, status pendidikan, lama menderita hipertensi dan keteraturan minum obat hipertensi. Berikut akan dijelaskan hasil secara umum dari 22 lansia dengan hipertensi yang mengikuti terapi kelompok suportif. 
Tabel 1. Distribusi Karakteristik lansia dengan hipertensi berdasarkan usia, dan tekanan darah $(n=44)$

\begin{tabular}{llcccc}
\hline Karakteristik & Kelompok & \multicolumn{1}{l}{ Mean } & Median & SD & Min-Max \\
Usia & Intervensi & 59,5 & 60,0 & 5,3 & $50-71$ \\
& Kontrol & 61,0 & 59,5 & 8,0 & $51-86$ \\
& Rata-rata & 60,3 & 59,7 & 6,7 & $50-86$ \\
\hline $\begin{array}{l}\text { Tekanan darah } \\
\text { Sistolik }\end{array}$ & Intervensi & 156,8 & 160 & 12,868 & $140-180$ \\
& Kontrol & 152,2 & 150 & 10,20 & $140-180$ \\
& Rata-rata & 154,5 & 155 & 11,53 & $140-180$ \\
& Intervensi & 97,73 & 100 & 8,12 & $80-110$ \\
$\begin{array}{l}\text { Tekanan darah } \\
\text { diastolik }\end{array}$ & Kontrol & 92,73 & 90 & 9,35 & $70-110$ \\
& Rata-rata & 95,23 & 95 & 8,73 & $70-110$
\end{tabular}

Dari table 1. terlihat bahwa kelompok intervensi dan kontrol memiliki tekanan darah sistole dan diastole yang sama besarnya. Dengan rata-rata sistole $156 \mathrm{mmHg}$ dan diastole $97 \mathrm{mmHg}$ menunjukkan lansia berada pada hipertensi stage 1 . Kondisi ini terjadi karena faktor bertambahnya usia.

Tabel 2. Perbedaan kualitas hidup sebelum dan sesudah mendapatkan terapi kelompok suportif pada kelompok intervensi dan kontrol $(n=44)$

\begin{tabular}{|c|c|c|c|c|}
\hline \multirow{2}{*}{ Kualitas Hidup } & \multicolumn{2}{|c|}{ Kelompok Intervensi } & \multicolumn{2}{|c|}{ Kelompok Kontrol } \\
\hline & Rerata & P-value & Rerata & P-value \\
\hline $\begin{array}{l}\text { Dom. FIsik } \\
\text { Sebelum } \\
\text { Sesudah } \\
\text { Selisih }\end{array}$ & $\begin{array}{l}17,59 \\
22,00 \\
4,41\end{array}$ & 0,001 & $\begin{array}{c}17,32 \\
17,59 \\
0,27\end{array}$ & 0,03 \\
\hline $\begin{array}{l}\text { Dom. Psikologis } \\
\text { Sebelum } \\
\text { Sesudah } \\
\text { Selisih }\end{array}$ & $\begin{array}{l}14,95 \\
20,23 \\
5,28\end{array}$ & 0,001 & $\begin{array}{c}14,86 \\
14,95 \\
0,09\end{array}$ & 0,329 \\
\hline $\begin{array}{l}\text { Dom. Sosial } \\
\text { Sebelum } \\
\text { Sesudah } \\
\text { Selisih }\end{array}$ & $\begin{array}{l}8,45 \\
11,18 \\
2,73\end{array}$ & 0,001 & $\begin{array}{r}8,32 \\
8,27 \\
-0,05\end{array}$ & 0,329 \\
\hline
\end{tabular}




\section{Dom. Lingkungan \\ Sebelum}

Sesudah

Selisih

Komposit

Sebelum

Sesudah

Selisih

Tabel 2 memperlihatkan bahwa kelompok intervensi memberikan hasil yang meningkat sebelum diberikan terapi supportif dibandingkan kelompok kontrol yang tidak diberikan perlakuan. Domain terbesar menunjukkan peningkatan kualitas hidup adalah domain lingkungan sebesar 7,22 point dan domain fisik yang perlu ditingkatkan lebih lanjut. Sedangkan pada kelompok kontrol tidak menunjukkan kenaikan yang besar.

\section{Pembahasan}

Penelitian ini menunjukkan adanya perubahan kualitas hidup lansia dengan hipertensi sebelum dan sesudah diberikan terapi supportif. Peningkatan pada setiap domainnya berbeda-beda. Paling besar terlihat pada domain lingkungan yaitu naik sebesar 7,22 point meliputi keamanan lansia saat terjadi peningkatan tekanan darah, lingkungan rumah dan kepuasan kerja sehari-hari. Walaupun hanya terjadi peningkatan yang sedikit kurang dari $10 \%$, namun hal ini patut diberi perhatian mengingat terapi yang diberikan baru 1 bulan lamanya, bagaimana jika diberikan intensif selama 6 bulan, tentu akan menunjukkan hasil yang lebih besar lagi.

Domain psikologis menunjukkan peningkatan kedua terbesar setelah domain lingkungan yaitu 5,28 point. Pada sesi 1 peneliti menggali masalah yang dapat menimbulkan kecemasan pada lansia dengan hipertensi. Paling banyak lansia cemas karena penyakit hipertensi yang tak kunjung sembuh justru semakin hari semakin tinggi saja, cemas karena tinggal jauh dari anak, cemas dengan kehidupan perkawinan anak-anaknya, cemas tinggal sendiri setelah ditinggal oleh pasangannya, cemas dengan penyakit lain yang diderita selain hipertensi memperberat kondisi psikologis lansia dengan hipertensi. Faktorfaktor penyebab cemas yang
0,001

19,86

19,95

0,09

15,09

15,19

0,10 muncul pada fase lansia sesuai dengan tugas perkembangan lansia. ${ }^{12}$

Support dari luar keluarga terlihat pada domain sosial yang meningkat sebesar 2,73 point. Domain ini muncul sejalan dengan meningkatkan domain fisik sebesar 4,41 point, hal ini disebabkan setelah lansia diberikan terapi kelompok suportif maka keempat domain tersebut ikut meningkat walaupun tidak dalam jumlah yang besar. Hasil penelitian menunjukkan bahwa lansia tetaplah makluk sosial yang tak bisa lepas dari lingkungannya, meskipun usia semakin bertambah, tetapi kebutuhan akan bersosialisasi tetap menjadi suatu kebutuhan lansia untuk mengatasi masalahmasalahnya. ${ }^{14}$ Kegiatan di lingkungan seperti senam bersama, membuat kerajinan yang dapat menghasilkan uang, pengajian dan sebagainya dijadikan lansia sebagai tempat untuk melepas stress di rumah, mengisi waktu luang dan menceritakan tentag kondisi sakit yang dialaminya di dalam kelompok lansia. ${ }^{15}$

Melalui pembentukan kelompok swabantu pada lansia dengan hipertensi, diharapkan dapat membantu meringankan masalah lansia seperti kecemasan sehingga dapat meningkatkan kualitas hidup lansia. Kelompok bernama "Dahlia Sehat" dapat secara berkala mendiskusikan masalah oleh masing-masing anggota. Setiap peserta mengungkapkan masalah yang dihadapinya, saling berbagi informasi bagaimana cara mengatasi permasalahan yang terjadi berdasarkan daftar masalah yang sudah dibuat dan mendiskusikan cara cara mencegah kekambuhan, tanda dan tanda kekambuhan dan tindakan yang dilakukan saat kekambuhan terjadi. ${ }^{16}$

\section{Kesimpulan}

Terapi supportif pada lansia dengan hipertensi secara signifikan dapat meningkatkan kualitas hidup lansia17. Selain 
itu terdapat perbedaan yang bermakna antara kelompok intervensi dengan kelompok kontrol setelah diberikan terapi supportif. Domain yang paling tinggi dalam meningkatkan kualitas hidup lansia adalah domain lingkungan dan psikologis. Pemberian terapi supportif dalam meningkatkan kualitas hidup lansia perlu diterapkan konsistensi pertemuannya dalam lingkungan Dahlia Senja

\section{Daftar Pustaka}

1. Nugroho. Keperawatan gerontik dan geriatri. Jakarta : EGC; 2013.

2. Riskesdas. Badan penelitian dan pengembangan kesehatan. Kementrian Kesehatan RI; 2013.

3. Rahadeng, Tuminah. Prevalensi hipertensi dan determinannya di Indonesia, Majalah Kedokteran Indonesia vol 59; 2009.

4. Stanley, Mickey dan Patricia Gauntlett Beare. Buku ajar keperawatan gerontik. Edisi 4., Jakarta: EGC; 2014.

5. Rohmah, Purwaningsih, Khoridatul Bariyah. Kualitas hidup lanjut usia. Jurnal Keperawatan. Vol 3, $120-132$

6. Darmojo, B. Buku ajar geriatri: ilmu kesehatan lanjut usia, Edisi 5 : Balai penerbit UI; 2006.

7. Guslinda. Pengaruh terapi kelompok terapeutik lansia terhadap kemampuan kelurahan surau gadang kecamatan adaptasi dan perkembangan integritas diri lansia di nanggalo padang. Tesis. Tidak Dipubliksikan; 2011.

8. Gabriella, et al. Health profile and quality of life of elderly with hypertension. Rev Rene ; 16(6):900-7; 2015.
9. Galih Widodo \& Puji Purwanigsih. Pengaruh meditasi terhadap kualitas hidup lansia yang menderita hipertensi di unit rehabilitasi sosial wening wardoyo unggaran kabupaten semarang. Jurnal Keperawatan Medikal Bedah. Volume 1, (2) ; 111-118; 2013.

10. Banon, E. Pengaruh terapi reminicence dan psikoedukasi keluarga terhadap kondisi depresi dan kualitas hidup lansia di katulampa bogor Tahun 2011. Tesis Tidak Dipublikasian; 2011.

11. Ignatavicus. Medical Surgical Nursing Critical Thinking For collaborative care (5th ed), St. Louis, Missouri; 2006.

12. Maryam, R. Siti, dkk. Mengenal Usia Lanjut dan Perawatannya. Jakarta: Salemba Medika; 2008.

13. Maria V. C, Liza B.S, Ana L.S, Paulo C. B, Veiga J. The Influence of Hypertensionon Quality of Life. Arq Bras Cardiol. 100(2):164-174; 2013.

14. Monika. Z, Aleksander.O, Adam E, Jerzy C, Comorbidities and the quality of life in hypertensive patients. Original Article 012; 122 (7-8)

15. Salim, Sudharma, Kusumaratna,dkk. Validitas dan reliabilitas WHO of life-BREF untuk mengukur kualitas hidup lanjut usia, Jurnal Universal Medicina volume 26, 27-38; 2007.

16. Sattanathan.K, Sagarika B.H, Prasanth K. S, Sara Y. Assessment of quality of life in hypertensive patients. Journal of Applied Pharmaceutical Science Vol. 6 (05), pp.143-147; 2016.

17. Tamher, S. dan Noorkasiani. Kesehatan usia lanjut dengan pendekatan asuhan keperawatan. Jakarta: Salemba Medika; 2009. 